Meta

Journal des traducteurs

Translators' Journal

\title{
Hommage à Irène Vachon-Spilka
}

\section{Jean-Paul Vinay et Daniel Gile}

Volume 32, numéro 4, décembre 1987

URI : https://id.erudit.org/iderudit/004566ar

DOI : https://doi.org/10.7202/004566ar

Aller au sommaire du numéro

Éditeur(s)

Les Presses de l'Université de Montréal

ISSN

0026-0452 (imprimé)

1492-1421 (numérique)

Découvrir la revue

Citer cette note

Vinay, J.-P. \& Gile, D. (1987). Hommage à Irène Vachon-Spilka. Meta, 32(4),

503-503. https://doi.org/10.7202/004566ar

Ce document est protégé par la loi sur le droit d'auteur. L'utilisation des services d'Érudit (y compris la reproduction) est assujettie à sa politique d'utilisation que vous pouvez consulter en ligne.

https://apropos.erudit.org/fr/usagers/politique-dutilisation/
Cet article est diffusé et préservé par Érudit.

Érudit est un consortium interuniversitaire sans but lucratif composé de l’Université de Montréal, l'Université Laval et l'Université du Québec à Montréal. Il a pour mission la promotion et la valorisation de la recherche. https://www.erudit.org/fr/ 
HOMMAGE À IRĖNE VACHON-SPILKA

La disparition d'Irène Vachon-Spilka est une lourde perte pour l'École de traduction de l'Université de Montréal. Esprit curieux, très au courant des faits et des théories de la traduction, Madame Spilka fut l'une de mes plus brillantes élèves. C'est même la seule qui soit venue s'inscrire à nos cours de linguistique en sachant parfaitement à l'avance où elle voulait aller, et par quelles voies. Comme Fernande Saint-Martin, à laquelle elle ressemblait par la vivacité de son intelligence, ce fut une des lumières de la révolution culturelle qui allait bouleverser les cadres universitaires québécois. Nous avons tous gagné à la connaître et à travailler avec elle au développement de la stylistique comparée au Canada. C'est un professeur et un chercheur qu'il sera difficile de remplacer.

JEAN-PAUL VINAY 